\title{
Alman Gençlik Edebiyatında Z-Kuşağı Etkisi: Bir Alanyazın Taraması Örneği
}

\author{
Neriman Nüzket Özen (D), Tekirdağ - Harun Göçerler (D), Tekirdă̆
}

https://doi.org/10.37583/diyalog.1030280

\section{$\ddot{\partial} z$}

2000'li yılların başından itibaren gençler sorunlarını, sevinçlerini, fikirlerini, hayat görüşlerini, yaşam tarzlarını pek çok farklı dijital platformda farklı kültürlerdeki ve ülkelerdeki gençler ile paylaşabilmektedir. Bu şekilde kendine has yeni bir yaşam felsefesi oluşturan ve Z-Kuşağı olarak anılan bir kuşak ortaya çıkmıştır. Bu çalışma, özellikle 2000 yılından sonra yazılmış olan Alman gençlik edebiyatı eserlerinden bazılarının örneklem olarak ele alınmasıyla bir alanyazın taraması yapmayı hedeflemektedir. $\mathrm{Bu}$ sayede Alman gençlik edebiyatında ele alınan konuların neler olduğu, hangi sebeplerden dolayı bu konuların ele alınmış olabileceği ortaya konmaya çalışılmıştır. İkincil hedef ise çalışmanın sonuç kısmında Türkiye'deki gençlik edebiyatı alanına ilişkin önerilerde bulunmaktır. Çalışmadan elde edilen sonuca göre Alman gençlik edebiyatında sıklıkla arkadaş ilişkileri, toplum içerisinde kimlik arayışı, okulu terk etme, uyuşturucu kullanımı ve doğurduğu sonuçlar, adaletsizlik, aile içi iletişim sorunları, ebeveyni ayrı olan gençlerin hikâyeleri, Cyber-Mobbing, aşk, bilimkurgu, göç, kültürlerarasılık, suç gibi konularının aktarıldığı tespit edilmiştir.

Anahtar Sözcükler: Alman Gençlik Edebiyatı, Gençlik, Z-Kuşă̆l, Okuma Alışkanlıkları.

\section{Abstract}

\section{The Generation Z Effect in German Youth Literature: A Literature Review}

Especially since the early 2000s, young people have been able to share their problems, joys, ideas, life views, and lifestyles with young people from different countries and cultures on various digital platforms. In this way, a generation known as Generation $Z$ has emerged with a unique life philosophy. This study aims to do a literature review by taking some of the German youth literature works written after 2000 as a sample. We tried to put forward what the subject matters dealt with in German youth literature are and why these subject matters have been chosen. The second aim of the study is to put forward suggestions on possible studies in Turkish youth literature. According to the results of the study, friendship, search for identity in society, dropping out of school, drug use and its consequences, injustice, family communication problems, life as a child of divorced parents, Cyber-Mobbing, love, science fiction, immigration, interculturalism, and crime are the subject-matters of German youth literature.

Keywords: German youth literature, Youth, Generation Z, Reading habits. 


\section{EXTENDED ABSTRACT}

The rapid digital transformation that manifested itself, especially in the 2000s, has radically affected the lifestyle of individuals and the cultural and ethical values of societies. While the rapid advancement of technology causes political, economic, religious, cultural, and social phenomena to be in a process of change and development faster than ever before, it has also led to the emergence of different perceptions of the concepts of time and space (Avc1 2021: 155). Among the groups that are most affected by this interaction, young people are perhaps the first to be affected. Especially since the early 2000s, young people have been able to share their problems, joys, ideas, life views, and lifestyles with young people from different countries and cultures on various digital platforms. In this way, a generation known as Generation $\mathrm{Z}$ has emerged, creating their unique life philosophy.

The concept of Millennium Youth is an umbrella term to refer to Generation Z (19962010) who lived their youth in the 2000s, and to refer to the Alpha Generation (2011-2025), who are still in the process of becoming adolescents at the time this article is written (see McCrindle, Fell 2020). The interests, needs, and problems of the aforementioned generation have started to attract attention in the literary field. Therefore, it is necessary to separate the literary works that have impacted the lives of the current young generation from the concept of children's and young adult literature, and it is high time we regarded them as under an individual heading entitled as youth literature.

When the reading habits of generation $\mathrm{Z}$ is examined, as Joachim H. Knoll (1982: 370) points out, when choosing literary works for young people to read, for many years, schools and adults have picked up works that are not of the kind of works preferred by young people at all. However, when young people are given the freedom to pick up works to read by themselves, it is observed that they do not only like reading, but they also tend to have a small library consisting of the literary books they like. It is obvious that generation $\mathrm{Z}$ likes to read contrary to the popular inion stating that they do not, but the types and appeal of the works and genres they read extensively influence their reading habits and tastes. (see Göçerler vd. 2017). At this point, the important thing is to lead young generations to read average but qualified works and not to lead them to read a lot, but without awareness.

The works of German youth literature written during and after the 2000s gradually moved away from the traditional concept of "Children's and Young Adult Literature," which naturally brought along a distinction in children's literature and youth literature. In the last quarter of the twentieth century, youth literature, which started to be known by its own name, started to have a semblance to the subject matters and formal characteristics of adult literature and started to construct new images about young boys, young girls, family, and social circle in the context of social change (see Nüzket Özen 2017). While subject matters such as illness, death, drugs, alcohol, sexuality, violence, domestic problems, and the adaptation problem of immigrants, which were previously considered problematic and sometimes taboo subjects, have started to be clearly addressed in the books, especially since the 2000 s, current issues such as war, refuge, and ecology have also become commonplace (Mikota 2015).

This study aims to do a literature review by taking some of the works of German youth literature written after 2000 as a sample. We tried to put forward the subject matters dealt with in German youth literature and why these subject matters have been chosen. The second aim of the study is to put forward suggestions on possible studies in Turkish youth literature. According to the results of the study, subject-matters such as friendship, search for identity in society, dropping out of school, drug use and its consequences, injustice, family communication 
problems, life as a child of divorced parents, Cyber-Mobbing, love, science fiction, immigration, interculturalism, and crime are tried to be reflected in German youth literature. Supernatural heroes have sometimes been included while reflecting these subject matters. 


\section{Giriş}

2000 yılı teknolojik yeniliklerin artmaya başladığı ve yeni medyaların ortaya çıkıp yaygın olarak kullanılmaya başlandığı bir dönemin başlangıcı kabul edilmektedir. Teknolojinin hızla ilerlemesi politik, ekonomik, dini, toplumsal, sosyal olguların her zamankinden daha hızlı bir değişim ve gelişim sürecinde olmasına neden olurken, zaman ve mekân kavramlarına dair farklı algılayış biçimlerinin ortaya çıkmasına da yol açmıştır (Avcı 2021: 155). Bu durumun hayatımıza yansımaları farklı biçimlerde gerçekleşirken günlük hayat rutinlerimizde yer alan çoğu olgu da yeni bir şekle bürünerek durmadan dönüşüme uğramaktadır. Hayat ve gerçekliğe ayna tutan, onun bir eşlikçisi olan edebiyatın da bu radikal değişim sürecinden nasıl etkilendiğini görmek için gençlik zamanlarını 2000'li yıllarda yaşayan neslin beğenisine yönelik ortaya çıkan edebi yapıtlara daha yakından bakmak yeterli olacaktır.

Çalışmanın araştırma nesnesi olan ve gelişimini temelde çocuk edebiyatı ile paralel sürdüren Alman gençlik edebiyatı, köklü ve uzun bir geçmişe sahiptir. İlk örneklerine Orta Çağ'da rastlansa da Alman çocuk ve gençlik edebiyatının bağımsız bir alan olarak edebi ürünler arasında yer almaya başlaması Aydınlanma dönemine denk gelir. 18. yüzyılın ikinci yarısında yaşanan bu gelişmeye özellikle Aydınlanma'nın getirdiği yeni fikir ve görüşler ile okuryazar oranının artması katkı sağlamıştır. Hans Heino Ewers de (1998: 20) Aydınlanma döneminin çocuk ve gençlik edebiyatı üzerindeki destekleyici etkisini ve bu türün ilk kez bu dönemde bir edebi araca dönüştüğünü vurgular. Çocuk imgesinde yaşanan radikal değişime, çocuğun da bir birey olarak fark edilmesine ve alıcı konumunda bir okur kitlesi olarak kabul görmeye başlamasına dikkat çeken Stephan'a göre (2008: 178) çocuk ve gençlik edebiyatı böylece kendine özgü bir alıcı kitlesi oluşturmaya başlamıştır.

Bu tür, Aydınlanma sonrasında Romantik dönem, Biedermeier dönemi, Birinci Dünya Savaşı, İkinci Dünya Savaş1, nasyonal sosyalizm, sürgün dönemi, savaş sonrası edebiyat ve modern eğilimlerle günümüze kadar farklı dönemlerden geçerek evrilmiştir. Bu dönemlerde çocuk ve gençlik edebiyatı ürünü olduğu toplumsal yapının geçirdiği her yeni süreçte farklı işlevler üstlenmiş, farklı çocuk ve genç imgeleri kurgulamış, farklı türlere örnekler geliştirmiş, bazen eğitici bir amaca hizmet ederken, bazen de siyasi propaganda aracı olarak kullanılmıştır. Freund (1996: 5) bu bağlamda çocuk ve gençlik kitaplarının, alıcı kitle olan çocuk ve gençlerin yaşadığı toplumda, varlıklarının o toplumsal yap1 için ne anlam ifade ettiği ve önem taşıdığı konusunda, onları bilinçlendirmek adına da birer aracı olduğunu vurgular. Bu edebi ürünler çocuk ve gençlere toplumdaki konumlarını yansıtır, okurlarına rutin hayatın olumsuz ve baskıcı gerçekliğinden kaçış imkânı sunarlar (Ostmeier 2002: 184). Çocuk ve gençlik edebiyatı eserleri ayrıca sosyalleşme aracı olarak da okurlarının siyasi ve sosyal düşünce yapısını etkileyerek zihinlerinde dünyayı yansıtan bir imge oluştururlar. Bu bağlamda Kaminski (1984: 88) kitapların birer sosyalleşme aracı olarak gençlerin siyasi ve sosyal açıdan arzu edilen varlıklar olarak yetiştirilmelerine de katkı sağladığını belirtir.

$\mathrm{Bu}$ noktada özellikle Alman çocuk ve gençlik edebiyatı kavramına bir açıklık getirmek gerekir. Çocuk ve gençlik edebiyatının birbirinden bağımsız birer alan olarak 
keskin sınırlarla ayrılabileceği düşüncesi uzun süre kabul görmemiştir. Özellikle Alman çocuk ve gençlik edebiyatı üzerine önemli çalışmaları olan Malte Dahrendorf ve Klaus Doderer de bu ayrımın doğru olmayacağını savunmuştur. Doderer'e göre (1992: 26) çocuk ve gençlik edebiyatı, yetişkin edebiyatında olduğu gibi böyle bir ayrıma uygun değildir ve bunu yapmaya çalışmanın, geçmişte onun bağımsız bir tür olarak gelişmesini olumsuz yönde etkilediğini belirtir. Dahrendorf (1996: 8) ise bu edebiyatın kendine özgü bir alıcı kitlesinin varlığını vurgulayarak ayrım yapmaktan ziyade, yetişkin edebiyatı ile çocuk ve gençlik edebiyatı arasında metinlerin adapte edilebileceğini ifade eder.

Ancak son yıllarda alanyazınında yapılan çalışmalarda, bu ayrımın ortaya çıkma gerekliliği üzerinde durulduğu fark edilmektedir. Kümmerling-Meibauer (2000: 254) çocuk ve gençlik edebiyatı kavramını, aslında henüz 'yetişkin' olmayan tüm okurlardan oluşan bir alıcı kitleye yönelik edebi ürünler üreten üst kavram olarak tanımlar. Ancak sonrasında bu tanımın bilimsel ve tatmin edici bir başarı sağlamadığını da ekler. Bu nedenle kimi zaman çocuk edebiyatı ile gençlik edebiyatı arasına bir çizgi çekme ihtiyacı doğmaktadır. Bu noktada yaş gruplaması dikkate alınan önemli ölçütlerdendir. Kaminski ise (1998: 65) gençlik edebiyatının bir geçiş edebiyatı olarak da görülebileceğini, artık çocuk edebiyatı kitaplarını okumak istemeyen ancak henüz yetişkin edebiyatına da mesafeli duran 11-16 yaş aralıklarındaki gençlere yönelik olduğunu belirtir. Bu bağlamda çocuk ve gençlik edebiyatı artık içeriksel ya da biçimsel ölçütlerden ziyade hangi okur grubuna yöneldiğine bağlı olarak tanımlanmaktadır. Ayrıca gençlerin davranış biçimleri, ilgi alanları, kullandıkları dil, sorunları ve olaylara ilişkin yorumları da çocuklara göre belirgin farklılıklar gösterdiği için okudukları edebi metinlerin de içerik olarak anılan bu noktaları göz önüne alarak üretilmiş olması gerektiği ve sırf bu yüzden artık gençlik edebiyatının çocuk edebiyatından farklı bir edebi tür olarak incelenmesi gerektiği savunulmaktadır (Şahin 1998: 6; Asutay 2003; Türkyılmaz 2012: 43).

Gençlik edebiyatı konusu Almanya özelinde kısaca ele alınacak olursa, Almanların gençlik edebiyatı kavramını içselleştirip her yıl binlerce ürün ortaya koymalarının birdenbire ortaya çıkan bir durum olmadığı görülecektir. Almanya'da 16. yüzyılda reform hareketlerinin doğuşu ile başlayan, matbaanın icadı ve yayılması ile devam eden ve kültürel anlamda da kilise odaklı eğitim felsefesi karşısında hümanistburjuva felsefesi odaklı eğitimin yer bulması, gençlik edebiyatına gitgide daha çok önem verilmesine yol açmıştır. Ayrıca hemen hemen aynı dönemde ortaya çıkan "genç kız" romanlarının da gençlik edebiyatının ilk örneklerinden olduğu söylenebilir (bkz. Neydim 2005). Genç kız romanlarında anne babaların ve müstakbel kocaların beğeneceği 'iyi' kızlar yetiştirmek gibi konular ele alınırken 20. yüzyılın ilk yarısına gelindiğinde Alman gençlik edebiyatında gençlerin büyük ölçüde nasyonal sosyalizmin fikir taşıyıcısı olarak görüldüğü politize olmuş bir konu seçiminden söz edilmektedir (Can 2000: 42). Özellikle 1940'lı yıllarda başlayan bu durumun akabinde dünyada, Avrupa'da ve Almanya'da ortaya çıkıp gençlerin de farklı biçimlerde etkilendiği birçok olay Alman gençlik edebiyatında konu seçiminde ve bu türün günümüze dek farklı evrelerden geçerek gelmesinde etkili olmuştur. Bu olaylar arasında günümüz gençliğini 
en çok etkilediği düşünüleni ise bilgi iletişim teknolojilerinin yaygınlaşmaya başlayıp özellikle sosyal medyanın etkisiyle gençliğin değer yargılarında köklü değişimlerin ortaya çıkmasıdır. Söz konusu durum tüm dünya gençliği üzerinde olduğu gibi Alman gençliği ve dolayısıyla onların beğenisine sunulan edebi eserlerde de kendini göstermiştir.

Bu sebepten çalışmanın amacı, milenyum olarak adlandırılan ve 2000 yılı itibari ile günümüze kadar etkisini devam ettiren yeni zaman diliminin Alman gençlik edebiyatı üzerindeki etkilerini alanyazın taraması yöntemi ile örnekler üzerinden ele alarak görünür kılmaktır. Öncelikle Milenyum adıla anılan zaman kesitine damga vuran ilk kuşak olan Z-Kuşağı gençliği kavramı üzerinde durularak bu genç grubun okuma alışkanlıklarına dair bilgiler aktarılacaktır. Çünkü Z-kuşağı gençliği günümüz gençlik edebiyatının konu alanlarının belirlenmesinde öncü bir role sahiptir. Günümüzde gençlik edebiyatı yazarlarının ana hedef kitlesi olarak görülen bu kuşağın özellikleri ve okuma alışkanlıklarına dair görüssler aktarıldıktan sonra 2000'li yıllarda gençlik yazınının geçirdiği içeriksel dönüşüm ele alınıp bunun günümüz Alman gençlik edebiyatındaki yansımaları örneklerle ele alınacaktır. Bu metin örnekleri de Alman çocuk ve gençlik edebiyatının özellikle 'genç' olarak nitelediği ve bunun tanımını da belli ölçütlerle kendi içinde açıkladığı okur grubuna yönelik yazılan ve okunan metinlerden oluşacaktır. Çalışmanın sonuç kısmında ise edebiyatın toplumsal değişim, dönüşüm ve gelişmeleri ne denli büyük bir hızla içselleştirip okurlarına metinler üzerinden yansıttığı ortaya konmaya çalışılacak ve önerilerde bulunulacaktır.

\section{Z-Kuşağı Gençliği}

Milenyum Gençliği kavramı ile işaret edilen genç nesil, her ne kadar kendilerine iradeleri dışında hitap edilen tanımlamalar olsa da gençlik yıllarını 2000'lerde yaşamış olan Z-Kuşağı Gençliği (1996-2010) ve bu makalenin yazıldığı dönemde henüz ergenliğe adım atma aşamasında olan Alfa Kuşağı Gençliği (2011-2025) olarak anılan gençlere atfen yapılan genel bir tanımlamadır (bkz. McCrindle, Fell 2020). Bu iki kuşağın doğum yılı aralıkları sosyologlar tarafından farklı kategorize edilse de genel olarak yukarıda anılan tarihler temel alınmaktadır (Atik 2019a: 36). Bu çalışmada $Z$ ve Alfa Kuşağı kategorilerinde anılan gençler arasındaki yaş farkı bir hayli fazla olsa da her iki kuşağın gençlik yıllarını 2000'lerde geçirecek olmaları onları bir anlamda milenyum gençliği tanımı altında birleştirmektedir.

Buna rağmen bu çalışmada daha ziyade günümüzde Z-kuşağının ilgi alanına giren Alman gençlik edebiyatı eserlerinin 2000'li yıllardaki dönüşümüne etkileri ele alınmaya çalışılacaktır. Bu yüzden günümüzde geleceğin mimarları olarak görülen $\mathrm{Z}$ Kuşağı gençlerinin genel karakteristik özelliklerine değinmekte fayda görülmektedir. Tapscott’a (bkz. 2009: 73-96) göre bu kuşağın özellikleri şu şekilde sıralanabilir:

a) Hayatta hür iradeleri ile hareket edebilme anlamında özgürlüğe sahip olma arayışında olma.

b) Toplum tarafından kendi kişisel kimlikleri ile kabul görme ihtiyacını benimseme. Yani toplum için toplumun istediği gibi bir karakter olmaktansa, kendi için kendini mutlu hissettiği karakter özellikleri ile davranma ve toplumca da bu şekilde kabul görme ihtiyacı. 
c) Karşılaştıkları durumları, kişileri, işleri bir mantık süzgecinden geçirerek sınamaya ihtiyaç duyma.

d) Özde dürüstlük ve adalet ilkesini benimsemek. Muhataplarından da aynı dürüstlüğü beklemek.

e) Kendilerine verilen işlerin ya da karşılaştıkları sorunların üstesinden gelmede iş birlikçi hareket etmenin önemine inanma.

f) Yaptıkları şeyden zevk almayı hep ön planda tutma.

g) Hayatta karar verme, anı yaşama ve iş bitiricilik anlamında hızı bir yaşam tarzını benimseme.

h) Her anlamda yenilikçi olma, yeni ve aykırı görünenden korkmama.

Söz konusu kuşağın toplumun geleceğini tayin etmedeki durumu beğeniler, yaşam şekli, öğrenim alanı seçimi, meslek seçimi, çalışma şekli gibi olgular göz önüne alınarak yorumlanacak olursa toplumsal bir alt hareketlenme ile birlikte sosyolojik ve kültürel bir dönüşümün hızla kendini göstermeye başladığı anlaşılabilir.

Bu çalışmada ele alınacak olan Z-Kuşağ gençliği, ister istemez kendinden sonra gelen diğer kuşak olan Alfa kuşağı gençlerine bilgi ve yaşam kültürü aktarma konusunda üzerine sorumluluk atfedilen bir nesil olacaktır. İki farklı başlıkta kategorize edilen bu kuşaklara dahil olan gençlerin, 2000'li yılların gençleri olmalarından dolayı birbirinden öğrenme, birbirini daha iyi anlama, birbirine karşı daha hoş görülü olabilme anlamında diğer nesillere göre kendileri arasında kuşak çatışmasına daha uzak bireylerden oluştuğu düşünülebilir. Fakat günümüzde özellikle Alfa kuşağı olarak tabir edilen ve sosyal ilişkilerinin büyük bir bölümünü sosyal ağlar üzerinden yönlendirme eğiliminde olan, akıllı telefonları yanında olmadığında kendini savunmasız hisseden, sanal oyunlar, haberleşme gibi hayatın olağan akışında yer bulan konularda dahi dijital dünyanın ürünlerinden faydalanan bireylerin önemli bir kesiminde sosyalleşmeye yarı kapalı kişiliklere dönüşme durumu söz konusudur (Bayhan 2013: 61). Özellikle içerisinde bulunulan yaş aralıkları dikkate alındığında ergenlik dönemi, ilk gençlik dönemi gibi dönemlerden geçmekte olan Alfa gençlerinin sorunlarını kendi içlerinde yaşamayı tercih ettikleri düşünülürse, yüz yüze iletişimde bulundukları diğer bireylere kendi sorunlarından bahsetmeyip, bunları daha ziyade dijital ortam platformlarında farklı şekillerde dile getiriyor olmaları belki de kuşak çatışmasından çok daha önemli başka sorunları beraberinde getiriyor olabilir (Baş 2017: 276). Tam da bu noktada ZKuşağı gençlerinden ve genç yetişkinlerinden edinecekleri bilgi ve deneyim aktarımının kalitesinin, aktarım şeklinin Alfa Kuşağının, dolayısıyla makro anlamda yakın gelecekte toplumun geleceği konusunda önemli bir rol üstleneceği düşünülmektedir. $\mathrm{Bu}$ düşünceden yola çıkarak Z-Kuşağı gençliğinin ilgi alanları, düşünüş tarzı, yaşam felsefesi, sanata bakışı gibi konuların sağlam temellere oturması oldukça önemlidir. Çünkü onlar Alfa gençlerinin öncüleri ve yol göstericileri olacaktır.

Yukarıda anılan genel özellikleri ile öne çıkan Z-Kuşağı gençlerinin sanat ve edebiyat konusundaki beğenilerinin de kendinden önceki kuşaklardan belirgin farkları olabileceğini söylemek yanlış olmaz. Sosyolojik bir takım etkileri de olan bu olası sorunlar, beklentiler ve beğenilerin hızla değişiyor olması 2000'li yıllarda gençlik yazınına da sıkça konu olmaya başlayan arkadaş ilişkileri, kimlik arayışı, okulu terk 
etme, madde kullanımı ve doğurduğu sonuçlar, adaletsizlik, aile içi iletişim sorunları, Cyber-Mobbing adıyla anılan dijital ortamlarda karşılaşılan psikolojik baskı ve şantaj, vb. alanlarda kendini göstermektedir (Üstten 2016: 605). Anılan tüm bu konu alanlarının edebi eserlerde yansımasının daha çok psikolojik romanlarda yer bulması ve bu türün gençler arasında sıkça tercih edilen bir roman türü olması da milenyum gençliğinin okuma tutumunun ne yönde ağırlık kazandığı konusunda yön gösterici olabilir (bkz. Göçerler 2020: 922).

Bir yerde gençlik kültürlerinin şekillenmesine etki edebilen başat faktörler olarak da ele alınabilecek bu konu başlıkları son on yılda modern toplumlarda karşılaşılan ve sıkça tartışılan bir olgu haline gelmiştir (bkz. Spatscheck 2014: 99). Dolayısıyla Z-Kuşağı gençliğinin içinde bulunduğu toplumsal durum, kendini sadece 2000'li yılların öncesine nazaran beğenilerin, yaşam algılarının, dünya görüşlerinin kökten ve hızla değişiyor olmasını ele alan edebi eserlerin salt kurmaca hikâyelerinde göstermemektedir. Aksine kurmaca içerisinde yoğun gerçekliğin ve yaşanmışlıkların anlatıldığı yazılar gittikçe daha çok üretilir hale gelmiştir. $\mathrm{Bu}$ olgu; kendini sadece Alman edebiyatı eserlerinde değil, diğer ülkelerin modern yazın ürünlerinde de göstermektedir. Çünkü bilgi iletişim teknolojilerinin yoğun etkisi altında yetişen gençlik, bilginin çok hızlı ve farklı kanallar aracılığı ile yayılmasının etkisiyle benzer konulardan etkilenir, benzer konulara ilgi duyar ve benzer konuları tartışır olmuştur (bkz. Spatscheck 2014: 99). Dolayısıyla tüm bu olgular Z-Kuşağı gençliğinin edebiyata bakışını ve okuma alışkanlıklarının değişimini de beraberinde getirmiştir denebilir. $\mathrm{Bu}$ bölümde aktarılanlardan yola çıkarak, çalışmanın bir sonraki bölümünde Z-Kuşağı gençliğinin okuma alışkanlıklarına ve tercihlerine daha detaylıca değinilecektir.

\section{Z-Kuşağı Gençliğinin Okuma Alışkanlıkları Üzerine}

Sosyo-ekonomik imkânların elverdiği ölçüde teknolojik destek sayesinde ihtiyaç duydukları tüm bilgilere kendinden önceki kuşaklara göre çok daha hızlı ve kolay erişebilme bilgi ve becerisine sahip olan günümüz gençliği, özellikle edebi metinlere erişme, metinleri ekrandan okuma ve okuyacağı metin türlerinin içeriği konusunda çok daha seçici olabilen bir kuşağı temsil etmektedir. Birçokları tarafından, günümüzde gençlerin artık gerçek anlamda edebi eserler okumadığ1, okur-yazar bir nesil olmaktan uzak bir gençliğin baş gösterdiği dünyadan söz edilse de durum aslında göründüğü gibi olmayabilir. Nitekim Göçerler tarafından yapılan bir anket çalışmasına katılan üniversite son sınıf öğrencileri genel olarak 'çok okuyan okur' kategorisinde yer almıştır (2020: 933). Aynı çalışmanın sonuçlarına göre öğrenciler, kitap okumak için en önemli unsurun okuma motivasyonu olduğunu dile getirmiş ve bunun da ders dişı bir etkinlik olarak zamandan ve mekândan bağımsız okumalar yapabilme ve kendi beğenilerine göre içerikler seçebilmek ile mümkün olabildiğini aktarmıştır (bkz. 2020: 928). Joachim H. Knoll'ün (1982: 370) de y1llar önce belirttiği gibi, söz konusu olan gençlerin okuyacakları edebiyat eserleri olduğunda uzun yıllar boyunca genelde yetişkinler ya da okul tarafından aslında hiç de gençlerin tercih edecekleri türden olmayan eserlerin belirlenip ne okuyacaklarının onlara söylendiğini görüyoruz. Fakat 
onlara okuma tercihlerini belirlemede özgür bir ortam sağlandığında ise gençlerin kitap okumanın yanı sıra beğendikleri edebi eserlerden oluşan küçük kütüphanelere sahip olma eğilimi gösterdiği de görülmektedir. Örneğin, Gündoğdu vd. (2016: 36) tarafından 15-19 yaş aralığındaki gençlerin okuma alışkanlıklarının incelendiği çalışmada yapılan ankete katılan 1002 öğrencinin \%59,2'si kendilerine ait bir kütüphaneye sahip olduğunu belirtmiştir. Aynı çalışmada anket katılımcılarının en çok okuduğu üç kitap türü ise sırasıyla bilim kurgu, edebiyat ve kişisel gelişim olarak sıralanmıştır. Solmaz' in (bkz. 2018: 619) üniversite öğrencileri ile yaptığı çalışmanın sonuçları da bu sıralamayı destekler niteliktedir.

$\mathrm{Bu}$ noktadan yola çıkarak, okumanın gençler arasında yaygınlaşmasının her şeyden önce bir alışkanlığa dönüşmesi ile mümkün olabileceği düşünülebilir. Nitekim okuma alışkanlığı kazanılmasındaki en önemli dönem "bedensel ve ruhsal değişmelerin yoğun biçimde yaşandığ 1 çocukluk ve gençlik dönemleridir” (Yılmaz, Köse ve Korkut 2009: 22). Konu bu noktadan ele alınacak olursa genç kuşağın okuma alışkanlığ kazanmasında ve eser seçiminde önde gelen noktalardan birisi de okudukları eserlerde kendilerinin ve kuşakdaşlarının sorunlarının ele alındığını görmeleridir. Hızlı yaşayıp hızlı tüketme özelliğine sahip Z-kuşağı gençliği bu anlamda beğeneceği kitabı seçme konusunda da kendi yönünü bulmuştur. Z-kuşağ1 gençlerinin, okuma etkinliğini genel olarak dijital ortamda gerçekleştirdiğini, bu manada doğrusal (linear) bir okuma gerçekleştirmediğini, aksine doğrusal olmayan (nonlinear) bir okumaya daha çok meyilli olduğunu dile getiren Pruim ve Halverson (2015: 258) bu gençlerin okuduğu dijital metinlerde seçici ve eleyici bir okuma tarzına yöneldiğini belirtmiştir. Bu durum aslında Z-kuşağı gençlerinin metin içeriğini hızlıca analiz edip o metni okuyup okumayacağına yine hızlı bir şekilde karar vermesinin de yolunu açmaktadır. Gençler bu şekilde seçmiş oldukları eserleri mobil cihazlarına dijital ortamda ücretsiz olarak kaydetmenin bir yolunu bulamadıklarında ise eserleri basılı kitap şeklinde temin edip okumaktadırlar (bkz. Göçerler: 2020).

Sonuç olarak Z-kuşağının belki de sanılanın aksine çok daha fazla okur olduğu, fakat okuduğu ürün türlerinin ve bu türlerin sunuluş biçimlerinin onların okuma alışkanlıklarını ve beğenilerini de büyük ölçüde etkilediği aşikârdır (bkz. Göçerler vd. 2017). Bu noktada önemli olan, genç nesilleri çok ama niteliksiz okumaya değil, ortalama ama nitelikli eserler okumaya yönlendirebilmektir. $\mathrm{Bu}$ düşünceler ile çalışmanın bundan sonraki bölümünde Alman gençlik edebiyatının Z-kuşağı gençliğine daha çok hitap eden 2000'li yılları kapsayan zaman dilimindeki içeriksel dönüşümü ele alınmaya çalışılacaktır.

\section{0'li Yıllar: Alman Gençlik Yazınının İçeriksel Dönüşümü}

Alman gençlik edebiyatında 2000'li yıllarda yazılmaya başlanan eserlerin geleneksel "Çocuk ve Gençlik" edebiyatı kavramından giderek uzaklaşmaya başlaması, edebiyatta bir çocuk/ genç ayrımı konusunu da sürecin doğal parçası olarak beraberinde getirmiştir. Değişimin öncesinde Schikorsky (2013) çocuk ve gençlik edebiyatında cevabı aranan ve 
cevapları belki yukarıda anılan sürece de etki edebilecek iki temel soruya dikkat çeker. Bu sorular şu şekilde sıralanabilir:

a) Günümüz dünyasında artık güven sorunu yaşayan ve kendi varoluş şartlarını sorgulayarak bir nevi hayal kırıklığına uğrayan toplumlarda, geleneksel çocuk ve gençlik edebiyatının eski temel ilkeleri devam ettirilebilir mi?

b) Yetişmekte olan gençlere hitap eden bir edebiyat, toplumsal şartlar değişse de okurlarına genel geçerliliğe sahip pedagojik değerleri, anlamları ve çözümleri aktarabilir mi?

$\mathrm{Bu}$ sorgulamanın temelinde yatan ise gelecekteki nesillere toplumsal norm ve değerleri aktarmak gibi işlevlere sahip olan geleneksel çocuk ve gençlik edebiyatı metinlerinin amaçlarının günümüzde okur beklentilerini karşılayamaz hale gelmesidir. Okurunu eğitmek, ona bir şeyler öğretmek, onu yetiştirmek gibi geleneksel amaçların yeniden ele alınıp araştırılmasının, günümüzde çocuk edebiyatı ve gençlik edebiyatı alanlarının birbirinden olabildiğince bağımsız ele alınmasına kapı aralayarak değişime giden yolu açmış olduğu söylenebilir.

Gansel'e (1998: 82) göre ise geleneksel kalıplardan uzaklaşmanın temelinde yatan sebep, içerik ve biçimsel açıdan üretilen yeni metinlerin artık çocuk ve gençlik edebiyatının dayattığ 1 geleneksel, katı ve 'yapay' tür sınıflamasında kendilerine yer bulamamasıdır. Gansel bu noktada çocuk ve gençlik edebiyatı ile yetişkin edebiyatı arasındaki sınırların da esneyerek daha geçişken ve kendine has olmaya başladığını belirtir. Bir yandan, gençlerin aslında daha üst yaş gruplarına hitaben yazılan eserlere ilgi göstermesi, diğer yandan da yetişkinlerin çocuk ve gençlere ait raflarda beğenilerine hitap eden eserleri arar hale gelmesi olağan görülmeye başlamıştır. Örneğin İngiltere'den Joanne K. Rowling'in Harry Potter (1991-2007) ya da Amerika'dan Stephanie Meyer'in Twilight serisi (2005-2008) gibi son yıllarda oldukça ilgi gören fantastik kitaplar, genç ve yetişkin okurlara hitap eden seriler olarak bu katı yaş sınıflamalarını esneterek çocuk ve gençlik edebiyatını genel anlamda etkilemiştir.

Yirminci yüzyılın son çeyreğinde artık kendi adı ile anılmaya başlanan gençlik edebiyatı, içerik açısından yetişkin edebiyatının ele aldığı konulara ve biçimsel özelliklere de yakınlık göstermeye ve toplumsal değişim bağlamında genç erkek, genç kız, aile ve çevreye dair yeni imgeler kurgulamaya başlamıştır. Kümmerling-Meibauer (2012: 78), anlatıcının eğitici rolünden sıyrılarak öznel yorumları bir kenara bırakıp tarafsız anlatıcı konumuna çekilmesini, Ben anlatıcısının ağırlıklı olarak öne çıkmasını, monologlar, bilinç akışı tekniği, zaman ve anlatı düzleminin hızla değişmesi ve çoğul bakış açısı ile gerçekleşen anlatımın gençlik edebiyatı eserlerinin içeriksel özellikleri arasında yer aldığını belirtir. Böyle bir anlatım tarzı aynı zamanda postmodern dünya gençlerinin çatışmalarını, parçalanmışlıklarını da resmetmeye uygundur. Özellikle anlatılarda sonuç kısmının yoruma açık bırakılması, genç okura sorunların giderilmesinde tek bir çözüm yolu ya da doğru göstermek yerine, kendi kararını verip yolunu özgürce biçimlendirebilmesi açısından onu kendi ile hesaplaşması konusunda düşünmeye sevk eden bir yenilik sunmuştur. Önceleri sorunlu ve kimi zaman da tabu konular arasında yer alan hastalık, ölüm, uyuşturucu, alkol, cinsellik, şiddet, aile içi sorunlar, göçmenlerin uyum sorunu gibi konular kitaplarda açıkça ele alınırken, özellikle 2000'lerde savaş, kaçış, ekoloji gibi güncel konular da olağan hale gelmiştir 
(Mikota 2015). Roman kahramanları da bu yeni gerçeklikleri yansıtmaya uygun imgeler olarak kurgulanmaktadır artık. Anita Schilcher 2001 yılında yaptığı araştırmada 82 adet güncel roman üzerinde çalışarak, geleneksel edebiyattan uzaklaşan 'yeni' çocuk ve gençlik edebiyatında değişen genç kız ve erkek figürlerini incelemiş ve kayda değer sonuçlar elde etmiştir. Araştırmaya göre romanlarda ağırlıklı olarak dişil figürler yer almakta ancak geleneksel genç kız imgesinin dışına çıkılmaktadır (bkz. Nüzket Özen 2017: 43). Bağımsız ve özgür genç kızlar ile modern genç kız imgesi kurgulanırken, genç erkek figürüne dair alışılagelen maceracı kahraman imgesinin de yok olmaya başladığı görülmektedir. Mikota (2015) geleneksel genç kız ve erkek imgelerinin değişime uğrayıp toplumsal rollerin artık belli bir cinsiyete sabitlenmemesi durumunun kitaplara yansırken birbiri ile çatışma ya da çeliş̧i şeklinde değil de, üzerinde tartışılabilen ve konuşabilen bir şekilde gerçekleştiğine dikkatleri çeker. Anlatıcının tarafsız bir anlatım ve üslupla yaklaşımı da bunu kolaylaştırmakta ve içeriği bir adım daha yetişkin edebiyatına yaklaştırmaktadır.

Günümüzde modern toplumların yapısında çok kültürlü bir yaşam tarzının ortaya çıkması da kültürlerarası iletişimi vurgulayan kitap örneklerini arttırmıştır. Huzur ve barış ortamında bir arada yaşamanın aktarımı gençlik kitaplarının diğer önemli içeriklerinden birisini oluşturmuştur. Bu içeriklerden bazılarına daha yakından bakmak amacıyla bir sonraki bölümde günümüz Alman gençlik edebiyatından örnek metinler ele alınmaya çalışılacaktır.

\section{Günümüz Alman Gençlik Edebiyatından Örnekler}

Alman gençlik edebiyatında 21. yüzyılın başında yaşanmaya başlanan içeriksel dönüşümü, yayınlar üzerinden örnekler vermeden önce bu dönüşüme küresel çapta öncülük ettiği söylenebilecek İngiliz yazar Joanne K. Rowling'in Harry Potter (19972008) serisine ve Stephenie Meyer' in Twilight serisine (2005-2008) değinmekte fayda vardır. Kendi türü üzerindeki etkisini günümüze kadar devam ettiren bu eserler, kendilerinden önceki eserlere nazaran yeni ve farklı bir yapıda olan kurguları ile dünyanın pek çok ülkesinde çocuk ve gençlik edebiyatına değişim ve dönüşüm adına yön vermiş, standartları temelden etkilemiştir. Macera, heyecan, arkadaşlık, gizem, bilim kurgu, kötüye karşı savaş gibi öğeleri harmanlayan Rowling, Harry Potter ile genç okurlara günlük hayat ile fantastik dünyayı bir arada sunmuştur. Küçük yaşta ailesini kaybeden Harry Potter yaşadığı duygusal boşlukları, büyücülük okulunda edindiği yakın arkadaşları ile girdiği maceralardaki dayanışma ve güven duygusu ile gidermektedir. İyi arkadaşlar ile birlikte çoğu zorluğun üstesinden gelinebileceğinin s1kça göz önüne getirildiği bu seri, sadece çocuk ve gençlerin değil birçok yetişkinin de ilgisini çekmiş ve sevilerek okunur hale gelmiştir.

Fantastik edebiyat ürünleri, Stephenie Meyer'in aşk, korku ve fantastik öğelerle dolu Twilight serisi (2005-2008) ile zirveye ulaşmıştır. Seride, taşraya babasına destek olmak amacıyla yanına taşınan Bella ile Edward isimli bir vampir ve aynı zamanda Jacob ismindeki bir kurt adamın arasında geçen aşk üçgeni anlatılmaktadır. Seride, kahramanların yaşadıkları birçok maceranın yanında hem aşkın önüne çıkan engellerin 
nasıl aşıldığı betimlenmiş hem de sevgi adına yapılan fedakârlıklara yer verilmiştir. Serinin sonunda kötü olana karşı, farklı türlerden de olsa iyi olanların ortak bir noktada birlik olabileceği ve kötülüğün üstesinden gelinebileceği çarpıcı bir anlatımla sergilenmektedir.

Kümmerling-Meibauer (2012: 75) Alman gençlik edebiyatında da bu türde eserler üreten yazarlara dikkat çekmektedir. En önemli isimlerden olan Kirsten Boie, Cornelia Funke ve Kai Meyer eserlerinde benzer motifleri kullanarak oldukça okunan yazarlardan olmuşlardır. Özellikle Cornelia Funke'nin Tintenwelt-Trilogie (2003-2007) serisi dünya çapında üne sahiptir. Kitaplara duyulan sevgi ve birisine kitap okumanın coşkusunu ele alan seride ciltçilik yapan Mo, kitaplarda yer alan varlıkları okuyarak onları gerçek dünyaya taşıma yeteneğine sahiptir. Ancak bunun karşılığında da insanlar kitapların içinde kaybolup gitmektedir. Kai Meyer ise 2001 yılında Merle-Trilogie ve 2003-2004 arası Wellenläufer-Trilogie ile gerçekçi ve fantastik anlatımı birleştirip mitolojik motiflere de başvurarak oldukça ün kazanan yazarlardan olmuştur.

Bu noktada Kümmerling-Meibauer (2012: 75) hem genç hem de yetişkin okura hitap ederek bu eserler için nesil ve yaş ayrımı yapmayan, edebiyatta yeni bir kavram olan “All Age Literatur"un doğduğunu vurgular. Schikorsky (2013), yayınevleri ve yazarların yöneldiği ve hedef kitlesini yediden yetmişe çok sayıda farklı okurun oluşturduğu All Age edebiyatının böyle rağbet görmesini ise okurda edebiyat için belli bir yaş sınıflaması bilincinin, yani okunan kitabın gençlere mi yoksa yetişkinlere mi yönelik olduğuna dair bilincin silinmeye başlamasına bağlamaktadır. All Age edebiyatına dahil edilen kitapların çoklu alıcı odaklı oluşu ve metinsel içerikte çocuk, genç, yetişkin bakış açılarının iç içe geçmiş olması okurların konuyu sabit ve tek yönlü alımlamasını da imkânsız kılmaktadır (Blume 2005: 37). Mikota'ya göre (2015) Almanya'da 1956 'dan bu yana verilen ve önemli bir ödül olan Alman Gençlik Edebiyatı Ödülü'nün (Deutscher Jugendliteraturpreis) son yıllarda sadece gençlik edebiyatında uzmanlaşmış yayınevleri dışında, genel edebiyat alanında yayın yapan yayınevlerinin kitaplarına veriliyor oluşu da bunun bir göstergesi olabilir.

Bir diğer yeni ve hibrit tür arasında "Steampunk Novel" yer almaktadır. Fantastik edebiyatın bir alt türü olarak gelişen "Steampunk Novel" bilim kurgu, fantastik öğeler, macera ve tarihsel romanın karışımıdır ve buhar teknolojisinin geliştiği Viktorya dönemi bu türün tarihsel arka planını oluşturur (Mikota 2015). Alternatif bir dünya tarihini konu edinen kitaplara en önemli örnek İngiliz yazar Richard Harland'ın retro fütüristik romanı Worldshaker-Trilogie'dir (2009). Almanya'dan ise Peter Schwindt Morland-Trilogie (2010) adlı üçlemesinde bilim kurgu ile tarihi bir arka planı harmanlayarak bu yeni türde yayınlar yapmış yazarlardandır. Mikota (2015) "Future Fiction" diye adlandırılan bir diğer türün oldukça popüler bir örneğinin Amerika'dan Suzanne Collins'in üçlemesi olan The Hunger Games (Açlık Oyunları 2008-2010) olduğunu ifade eder. Ekolojik bir sorunsalın distopik öğelerle bir arada ele alındığ bu türe Almanya'dan ise Thomas Thiemeyer'in Das verbotene Eden (2011-2013) serisi örnektir. 
Gençler için tekrar popüler hale gelen ve geçmişi aslında 1929 y1lına Erich Kästner'in Emil und die Detektive adlı çocuk kitabına dayanan bir tür de Kriminalroman'dır. Kästner'in toplumsal sosyal gerçekliği doğrudan yansıttığı bu kitabında çocukları hedef okur olarak gören kurmaca bir polisiye söz konusudur (Kümmerling-Meibauer 1999: 512). Kästner'in varisi sayılabilecek pek çok yazar arka planda büyük şehir ortamını seçip, gerçek yaşamdan tanıdık gelen roman kahramanları ile toplumsal yapının değer yargılarını ve ahlaki değerlerini tartışan heyecan dolu polisiye maceraları kaleme almıştır. Alman gençlik edebiyatında bu türde yazan önemli yazarlardan birisi, Alman Gençlik Edebiyatı Ödülü ve Erich Kästner Edebiyat Ödülü dahil çok sayıda ödül alan Andreas Steinhöfel'dir. Steinhöfel, Rico, Oskar und die Tieferschatten (2008) romanında kurguladığı iki farklı erkek çocuğu imgesi ile gençlik edebiyatında erkek çocuk imgesinin değişiminde de önemli bir rol oynamıştır. Romanda iki yakın arkadaş olan Rico öğrenme ve hafıza sorununa sahipken, Oskar üstün yeteneklidir. Birbirlerinin güçlü ve zayıf yönlerini kabul ederek, endişe ve korkularını paylaşan bu iki arkadaştan polisiye olayını çözen ise engellerine rağmen Rico'dur. Oskar her ne kadar üstün yetenekli olsa da korkuları olan bir çocuktur ve her yere kaskı ile gider. Lange (2005: 525) bu kitapta içsel monologlar, sürekli perspektif değişimi ve bilinç akışı tekniğinin kullanılmasını yeni nesil gençlik polisiyesinin özellikleri olarak sayarken, böylece çocuk ve gençlik edebiyatında yüzyıllardır süregelen 'güçlü' olanın kazanması kurgusunun da sarsılarak özellikle erkek okura yeni bir erillik imgesinin sunulmuş olduğunu vurgular.

2000'li y1llarda ön plana çıkan farklı bir tür de çoklu kültüre sahip bir toplum yaşantısının beraberinde getirdiği ve kültürlerarasılığg vurgulayan Interkulturelle Jugendliteratur başlığı altında yer alan gençlik kitaplarıdır. Yirmi birinci yüzyıl, uluslararası ilişskilerin bir ağ gibi birbirinin üzerini örerek gelişmeye devam eden kaçınılmaz bir kültürleşmeye de neden olurken "Yabancı" ile karşılaşma sıkça yaşanılan bir tecrübe olmaya başlamıştır. Büker ve Kammler (2003: 7) kültürel farklılıkların bu durumda artık bir istisnadan ziyade normallik olarak görülmesi ve buna uygun davranış biçimleri ile toplumsal demokratik birlikteliğin geliştirilmesi gerekliliğini vurgular. Her türlü toplumsal olguyu bir ayna gibi yansıtan gençlik edebiyatı da yabancı olanı kurgulaması, ona dair yaşanan deneyimleri öznel örneklerle somutlaştırıp okuruna sunması adına bu kültürel değişime uyum sağlamıştır. Hem sorun odaklı hem de iletişimsel bir işleve sahip olan bu kitaplar Weinkauff'a göre (2005: 766) misafir işçi çocukları, başörtülü kızlar ve göçmen edebiyatı olarak üç grupta toplanabilir. Weinkauff (2005: 769) bu kitapların, karakteristik bir özellik olarak yabancı işçilerin aileleri ile Almanya'ya göç ettikten sonraki hayat şartlarını ve iki kültür arasında kalmalarını ele aldığını belirtir. Geldikleri memleketlerini özlemle anmalarının olumlu, yeni bir kültüre girişte yaşadıkları deneyimlerin ise olumsuz çağrışımlarda bulunması olağanken, kitaplarda yabancı ile uyum içinde yaşamanın idealleştirilmesinden çok, aşırı sağcılık ve sınır dışı edilme gibi sorunlar da dile getirilmektedir. Özellikle kendileri de birer yabancı olan yazarların çoğalarak, kendi yaşamlarından tecrübeleri kitaplarda kaleme almaları kurguyu daha gerçekçi hale getirerek ilgi çekmektedir. 
Birçok ödüle sahip Alman yazar Antonia Michaelis, Kreuzberg 007 (2009-2011) adlı serisinde kültürlerarasılık düşüncesini 21. yüzyıl Berlin'inde ele alarak çoklu kültürel bir yapı içerisinde büyüyen çocuklardan oluşan bir grubun başından geçenleri yazmış ve oldukça rağbet görmüştür. Kirsten Boie'nin 2012'de yayınlanan Der Junge, der Gedanken lesen konnte adlı polisiye romanında olaylar annesi ile Kazakistan'dan göç eden Valentin'in bakış açısından anlatılmaktadır. Valentin, yeni çevresini tanımaya çalışırken Mesut ile tanışır ve bir suç olayını beraber çözerler. Boie'nin bu kitabında yeni olan kurgusal olgu anlatıcı perspektifinin değişmesi ve olayların göçmenlik geçmişi bulunan bir gencin ağızından doğrudan aktarılmasıdır. Çok kültürlü yapıya sahip bir toplum yaşantısının ele alındığı kitaplara ise Deniz Selek'in romanları örnek gösterilebilir. Üç yaşındayken ailesi ile Almanya'ya göç eden yazar, aile imgesi üzerinden her iki kültür arasında yaşamanın örneklerini okuruna sunarken konuya mizah ile yaklaşıp Türkiye'deki hayattan kesitler de yansıtmaktadır. Aprikosensommer (2015) adlı romanında okurlarına Türkiye'yi modern ve dışa dönük bir ülke olarak yansıtırken, var olan bazı sorunları da masumlaştırmadan olduğu gibi ifade eder. Mikota'ya (2015) göre gençlik edebiyatında yaşanan bu değişimi konu edinen kitapların temel ortak özelliği gençlere doğrudan çözüm yolları sunmak yerine onları hayatın bir gerçeği olan olgular ve olaylar üzerinde düşünmeye sevk ederek ucu açık bir anlatımla sonlanmasidir.

Tüm bu örneklere ilave olarak Oktay Atik'in (2019 b) tamamlamış olduğu doktora çalışmasında ele aldığı ve Alman gençlik yazını kategorisinde değerlendirilebilecek olan Sarah Darer Littman'1n Die Welt wär besser ohne dich, Alice Gabathuler'in Matchbox Boy, Johanna Nilsson'un Hass gefällt mir, Katrin Stehle'nin Passwort in dein Leben, Manfred Theisen'in Weil es nie aufhört ve Agnes Hammer' in Ich blogg dich weg! adlı eserlerinde ele alınan konuların da bu çalışmada değerlendirilenlerden farklı olmadığı görülür. Nitekim eserlerin isimlerindeki çağrışımdan da kişisel bir dışa vurum ihtiyacının mevcut olduğu anlaşılabilir. Dolasıyla konu özelinde bir genelleme yapılacak olursa, genç neslin yaşamına olumlu ya da olumsuz yönden dokunan her durumun gençlik edebiyatında mutlaka bir şekilde yer bulduğu söylenebilir. Bu durum toplumsal dönüşüm ve değişim süreçlerinin edebiyat alanındaki yansımasının somut bir örneği olarak değerlendirilebilir.

\section{Sonuç}

Dijital imkânların yaygınlaştığı, kişilerarası ilişkilerin sınırlar ötesine taşınmasının kolaylaştığı, toplum içi ilişkilerin de dijitalleşmedeki yaygınlaşmaya paralel olarak değişime uğradığı 2000'li yıllar, özellikle genç nesil içerisinde hayata karşı farklı bir duruş sergilemeyle ilgili kişisel gelişim süreçlerindeki değişimi hızlandırmıştır. Gençlerin yaşayış ve hayata bakış şekillerinin alışılagelenden daha farklı olmaya başladığı bu yıllarda, edebiyat eserleri ve bu eserlerin ele aldığı konular üzerinde de köklü değişimlerin olduğu görülmektedir. Gerek biçimsel gerekse içerik açısından modern ve postmodern öğeleri, metinlerarasılık ve medyalararasılık ilişkilerini içeren bu kitaplar, okurlarına farklı okuma şekilleri, olay kurgusuna dair farklı sonlar ve çözüm 
imkânları hayal etme gibi alternatifler sunmaktadır. Trajik öğelerin yanı sıra mizahın da yer alması kitapları sınıflayarak belli bir türe dahil etmeyi de artık mümkün kılmamaktadır. Tüm bu değişim alanyazınında kendine has türler olan kız ve erkek çocuğu edebiyatını da büyük ölçüde etkileyerek cinsiyet rollerini temelden sarsıp, farklı genç kız ve genç erkek imgeleri yaratmıştır.

Edebiyatın temelde toplumun yazı dilindeki yansıması olduğu görüşünden hareketle, söz konusu değişimlerin edebi eserlerde kendini hızla göstermesi, aslında olması gerekenin olmakta olduğunun ispatıdır. 2000 sonrasında özellikle arkadaşlar arası ilişkiler, toplum içerisindeki kimlik arayışı, gençlerin okul çevresinde yaşadığ sorunlar, madde bağımlılığı ve bunun doğurduğu psikolojik sonuçlar, adalet eksikliği duygusu, aile içi iletişim, parçalanmış aileler ve bunun gençlerin yaşamındaki yansımaları vb. gençlerin hayatlarından alınan gerçek örneklerden yola çıkarak edebi eserlerde farklı kurgular içerisinde yer bulmaya başlamıştır.

$\mathrm{Bu}$ ve benzeri konu başlıkları internetin ve dijital iletişim kanallarının sağladığ sayısız imkânlarla gençler arasında uluslararası ölçüde tartışılır hale gelmiştir. Dolayısıyla örneğin; İngiltere'deki gençlerin sorunları ile Almanya'da veya Türkiye'deki gençlerin karşılaştıkları sorunlar, temelde aynı başlık altında ele alınabilecek konuları içermektedir. Fakat bunlar sosyo-kültürel değişkenlerden ötürü farklı biçimlerde cereyan eden hadiselere örnekler olarak edebi eserlere konu olmuş ve okuyucunun değerlendirmesine sunulur hale gelmiştir. Bu çalışmada Alman gençlik edebiyatından sınırlı sayıda eser örneği verilmiş olsa da, diğer birçok eserin ele aldığ konu başlıklarının da temel olarak yukarıda anılan konular çerçevesinde kategorize edilebileceği söylenebilir. Çalışmada da görüldüğü üzere Alman gençlik edebiyatından verilen örnekler bağlamında kitaplarda üç farklı konu alanının öne çıktığı görülmektedir: Mitolojik öğeler, fantastik ve bilim kurgu öğeleri ile gençlerin gündelik hayatlarında yaşadıkları gerçekliğe dair öğeleri yansıtan konu alanları.

Alman gençlik edebiyatı eserlerinde olduğu gibi Türkiye'de yazılan gençlik edebiyatı ürünlerinin de gençlerin genel psikolojik ve sosyolojik sorunlarından hareketle oluşturulduğu ve bunların çoğunun yaşanmış hikâyelerden esinlenerek üretildiği düşünülecek olursa, bu eserlerin sosyo-psikolojik temeller çerçevesinde analiz edilmesinde fayda görülmektedir. Özellikle ülkemizdeki Z-Kuşağı gençliğinin temel sorunları, nelere eğilim gösterdikleri, onların düşünme şekillerinin nasıl evrildiği, sorunlara nasıl yaklaştıkları ve ne tarz tepkiler verebilecekleri, sevdikleri konular gibi noktalarda gerçekçi fikirler edinilebilir. Gençlik edebiyatından alınan bu gibi yardımların da göz önünde bulundurulması ile Z-Kuşağı gençliğinin daha iyi anlaşılması ve bu sayede ihtiyaç duydukları alanlarda kendilerine etkin destekler sunmak mümkün olabilecektir. Önemli olan, olaylara gençlerin gözünden de bakabilmek ise, gençlik edebiyatı eserlerinin analizinin göz ardı edilmesi söz konusu olmamalıdır. Bu bağlamda alanyazınında etkili kalemlerin yetiştiği Alman gençlik edebiyatı eserlerinin de göz ardı edilmemesi önerilir.

Alanyazınında yapılacak bundan sonraki çalışmalar için Alman gençlik edebiyatı eserlerinin analizinden yola çıkarak Türkiye'de ortaya çıkan gençlik edebiyatı 
eserlerinin de analizleri yapılarak karşılaştırmalı edebiyat çalışmalarının ortaya konulmasının gereğini vurgulamakta fayda vardır.

\section{Kaynakça}

Asutay, Hikmet. (2003): Der Adoleszenzroman in der türkischen Jugendliteratur und Literaturunterricht in der Türkei. Zeitschrift für Interkulturellen Fremdsprachenunterricht [Online]. 8(1). http://www.ualberta.ca/ german/ejournal/asutay2.htm (Son Erişim: 20.01.2021).

Atik, Oktay (2019a): Dijital Kuşak, Türk-Alman Gençlik Alt Kültürleri ve Almanca Öğretimine Yazınsal Bir Bakış. Alman Dili ve Kültürü̈ Araşttrmaları Dergisi. 1(2), 36-45.

Atik, Oktay. (2019b): Die Generation „Digital Natives“ und ihre Widerspiegelung in aktuellen deutschen Jugendromanen: Eine Gegenüberstellung soziologischer und literarischer Generationsanalyse, (Trakya ve Namık Kemal Üniversitesi, Sosyal Bilimler Enstitüleri, Alman Dili ve Edebiyatı Ortak Doktora Programı, Yayınlanmamış Doktora Tezi), Edirne.

Avcı, Mehmet Güven (2021): Zaman - mekân sıkışması, küreselleşen salgın ve toplumsal sonuçları. OPUS - Uluslararası Toplum Araştırmaları Dergisi. 17, 3787-3807.

Baş, Halim (2017): Türkiye'de Genç Nüfus: Sorunlar ve Politikalar. Süleyman Demirel Üniversitesi Sosyal Bilimler Enstitüsü Dergisi. 2 (27), 255-288.

Bayhan, Vehbi (2013): Gençlik, Sosyal Medya ve İnternet Bağımlılığı. Düşünce Dünyasında Türkiz Siyaset ve Kültür Dergisi. 4 (23), 61-80.

Blume, Svenja (2005): Texte ohne Grenzen für Leser jeden Alters: Zur Neustrukturierung des Jugendliteraturbegriffs in der literarischen Postmoderne. Freiburg: Rombach Verlag.

Büker, Petra \& Kammler, Clemens (2003): Das Fremde und das Andere in der Kinder- und Jugendliteratur. Weinheim: Beltz Juventa.

Can, Özber (2000): Türk çocuk ve gençlik edebiyatı ile Alman çocuk ve gençlik edebiyatının dünü ve bugünü. Ankara Üniversitesi Dil Dergisi. 95, 1-48.

Dahrendorf, Malte (1996): Vom Umgang mit Kinder- und Jugendliteratur. Berlin: Volk und Wissen Verlag.

Doderer, Klaus (1992): Literarische Jugendkultur. Kulturelle und gesellschaftliche Aspekte der Kinder und Jugendliteratur in Deutschland. München: Juventa-Verlag.

Dykstra-Pruim, Pennylyn / Halverson, Rachel, J. (2015): New Media Texte für die Millennials im DaF Unterricht. Die Unterrichtspraxis/ Teaching German. 48 (2), 255-274.

Ewers, Hans-Heino (1998): Kinder- und Jugendliteratur der Aufklärung. Ditzingen: Reclam Verlag.

Freund, Walther (1996): Deutsche Kinder- und Jugendliteratur der Gegenwart. Bonn: Inter Nationes.

Gansel, Carsten (1998): Phantastische und moderne Literatur für Kinder und junge Erwachsene. Der Deutschunterricht. Heft 6, 78-82.

Göçerler, Harun (2020): Yabancı Dil Son Sınıf Öğrencilerinin Okuma Alışkanlıkları Üzerine Durum Tespiti Çalışması. Uludağ Üniversitesi Eğitim Fakültesi Dergisi. 33 (3), 917-941.

Göçerler, Harun / Atik, Oktay / Demir, Meryem (2017): Die Förderung der Lesegewohnheiten mittels neuer Medien im Deutschunterricht für das Leseverstehen. H. Asutay (Editör), Balkan Educational Studies. Edirne: Trakya University Publication No: 188, 264-279. 
Gündoğdu, Cemal / Barata, Begüm / Çelebi, Evrim (2016): 15-19 Yaş arası gençlerin kitap okuma alışkanlıklarının incelenmesi: Elazı̆̆ il örneği. Ĕ̆itim ve Öğretim Araştırmaları Dergisi. 5(2), 36-42.

Kaminski, Winfred (1984): Zeitgeschichtliche und Politische Kinder- und Jugendliteratur. Kinder- und Jugendliteratur. Ein Handbuch. Gerhard Haas (Ed.) Stuttgart: Reclam, 88-109.

Kaminski, Winfred (1998): Einführung in die Kinder-und Jugendliteratur. Literarische Phantasie und gesellschaftliche Wirklichkeit. München: Weinheim.

Kümmerling-Meibauer, Bettina (1999): Klassiker der Kinder- und Jugendliteratur. Ein internationales Lexikon. Band: 1. Stuttgart: Metzler.

Kümmerling-Meibauer, Bettina (2000): Kinder-und Jugendliteratur. Reallexikon der deutschen Literaturwissenschaft. Band II. Fricke, Harald u.a (Ed). Berlin: De Gruyter, 254-258.

Kümmerling-Meibauer, Bettina (2012): Kinder- und Jugendliteratur. Eine Einführun.. Darmstadt: WBG, 254-258.

Knoll, Joachim. H. (1982): Das Leseverhalten Jugendlicher - Ausdruck des gegenwärtigen Zeitgeistes? Zeitschrift für Religions- und Geistesgeschichte. 34 (4), 370-379.

Lange, Günter (2005): Krimis für Kinder und Jugendliche. Günter Lange (Ed.) Taschenbuch der Kinderund Jugendliteratur. Band 1: Grundlagen - Gattungen. Hohengeren: Schneider Verlag.

McCrindle, Mark / Fell, Ashley (2020): Understanding Generation Alpha. Norwest: Mc Crindle Research Pty. Ltd.

Mikota, Jana (2015): Trends und Tendenzen. Ein Blick auf die deutschsprachige Kinder- und Jugendliteratur nach der Jahrtausendwende. https://iteraturkritik.de/id/21385 (Son Erişim: 12.01.2021).

Neydim, Nejdet (2005): Genç Kız Edebiyatı. İstanbul: Bu Yayınevi.

Nüzket Özen, Neriman (2017): Alman Genç Kız Edebiyatı Bağlamında Genç Kız İmgesinin Toplumsal Cinsiyet Araştırmaları ile Analizi. Geleneksel Der Trotzkopf Romanından Modern Lady Punk Romanına Değişim Süreci. DIYALOG Interkulturelle Zeitschrift für Germanistik. 5 (2), 30-47.

Ostheimer, Astrid (2002): Computerspielwelten und virtuelle Realität in der aktuellen phantastischen Literatur. H.-H. Ewers (Ed.): Lesen zwischen Neuen Medien und Pop-Kultur. Weinheim/ München: Juventa Verlag, 163-186.

Schikorsky, Isa (2013): Grenzüberschreitungen: Trends und Tendenzen in der deutschen Kinder-und $\begin{array}{lllll}\text { Jugendliteratur } & \mathrm{zu} & \text { Beginn } & \text { des } & \text { Jahrhunderts. }\end{array}$ https://www.kinderundjugendmedien.de/index.php/literatur/104mediageschichte/literaturgeschic hte/663-schikorsky-grenzueberschreitungen-kjl-21-jahrhundert (Son Erişim: 17.03.2021).

Schilcher, Anita (2001): Geschlechtsrollen, Familie, Freundschaft und Liebe in der Kinderliteratur der 90 er Jahre. Studien zum Verhältnis von Normativität und Normalität im Kinderbuch und zur Methodik der Werteerziehung. Berlin: Peter Lang Verlag.

Solmaz, Mustafa (2018): Üniversite Öğrencilerinin Okuma Alışkanlığg Üzerine Bir Araştırma: Yüzüncü Y1l Üniversitesi Örneği. Türkiye Sosyal Araştırmalar Dergisi. 22 (2), 603-622.

Spatscheck, Christian (2014): Toplum ve Gençlik Kültürleri - Gençlik Çalışması İçin Yorumlar ve Sonuçlar. Kurtaran, Y./ Yurttagüler, L. (Ed.): Gençlik Çalışmaları Tarihi. İstanbul: İstanbul Bilgi Üniversitesi Yayınları, 99-114.

Stephan, Inge (2008): Entstehung der Kinder- und Jugendliteratur. Aufklärung. Beutin, Wolfgang (Ed.): Deutsche Literaturgeschichte. Von den Anfängen bis zur Gegenwart. Stuttgart: J.B. Metzler Verlag, 178-180. 
Şahin, Yelda (1998): Jugenliteratur in Deutschland und in der Türkei ein analytischer Themenbereich. Mersin Üniversitesi, Sosyal Bilimler Enstitüsü, Alman Dili ve Edebiyatı A.B.D., Yayınlanmamış Yüksek Lisans Tezi. Mersin.

Tapscott, Don (2009): Grown Up Digital - How the Net Generation Is Changing Our World, New York: Mc Graw Hill.

Türkyılmaz, Mustafa (2012): Gençlik Romanlarının Okuma Becerisine Etkisi ve Değerler Aktarımı Bakımından İncelenmesi. Gazi Üniversitesi, Eğitim Bilimleri Enstitüsü, Ortaöğretim Sosyal Alanlar Eğitimi Bölümü, Türk Dili ve Edebiyatı Eğitimi A.B.D., Yayınlanmamış Doktora Tezi. Ankara.

Üstten, Aliye Uslu (2016): Gençlik Edebiyatı Eserlerinde Gençlik Sorunlarının Yansıtılış Biçimleri Üzerine Bir Değerlendirme. Turkish Studies.11 (20), 605-616.

Weinkauff Gina (2005): Multikulturalität als Thema der KJL. Günter Lange (Hrsg.) Taschenbuch der Kinder- und Jugendliteratur. Band 1: Grundlagen - Gattungen. 2. Auflage. Hohengeren: Schneider Verlag, 766-783.

Yılmaz, Bülent / Köse, Eda / Korkut, Şelale (2009): Hacettepe Üniversitesi ve Bilkent Üniversitesi öğrencilerinin okuma alışkanlıkları üzerine bir araştırma. Türk Kütüphaneciliği. 23 (1), 22-51. 